\title{
Monitoring of the Dynamics of Changes of the Human Adaptive Norm in Cyberphysical Systems of "Smart Buildings" Using Digitalization
}

\author{
Chulkov V.O.
}

\author{
Moscow State University of Civil Engineering, Moscow Russia. \\ Association "Infographic basis of functional systems" of the Russian section of the International Academy of Sciences, \\ Moscow, Russia. \\ *Corresponding author. Email: E-mail: vitolch@gmail.com
}

\begin{abstract}
In the cyberphysical systems of "smart buildings", digitalization is an indispensable basis for the entire total of processes of instrument monitoring and management of the numerous parameters of the functioning of the structure. This functioning implies a variety of aspects, including integrated security, comfort of life, industrial activity or just human living. The basic model of such functioning is considered to be the infographic system "person-technics-environment, RTE", capable of fully and unambiguously set parameters, limitations and modes of instrument monitoring and management processes in a "smart building". Digitalization of management and decision-making automation reduce the number of managerial personnel, increase the reliability of management, ensure the effectiveness of made decisions, increase profits and save resources. In Russia, unlike the foreign practice of digitalization, there are no outdated digital monitoring and management platforms. There is an opportunity to quickly and fully integrate new original domestic developments. An example of the possibility of implementing digitalization technologies for monitoring and management can be the control of changes of the adaptive norm of a particular person in a dynamically changing environment. Domestic and foreign practice of study in this direction can be effectively combined with the currently actively developing study of cyberphysical systems and the digitalization of management of them. For this purpose, it is advisable to use the theory and practice of infographic modeling in combination with anthropotechnical management. The multilayer hierarchical infographic models, used for this, illustrate the ontology of terms and definitions of the science of interrelations and management in society, technics and the environment (cybernetics).
\end{abstract}

Keywords: digital management, multilayer models, digital economy, infography, cyberphysical systems,

anthropotechnical management, computer monitoring

\section{INTRODUCTION}

The term and concept of "cyberphysical systems" are associated with cybernetics, which studies the general mechanism of the processes of management and transmission of information in biological, technical, public and other systems. The ontology of the development of cybernetics has been known since the 5th century BC. A front burner is occupied by Andre-Marie Ampère (put into circulation the term "cybernetics", 1834 [1, 2, etc.]), A.A. Malinovsky-Bogdanov ("tectology", 1913-1922 [3]), L. von Bertalanffy (general theory of systems, 1930 [4]), P.K. Anokhin (direct and reverse afferentation in the functional systems of the human body, 1930-35gg [5, etc.]), J. von Neumann (cybernetics as a field of application computers, 1943-46 [6, 7, etc.]), N. Wiener (feedforward and feedback management in living organisms and machines,
1948 [8, 9, etc.]), K. Steinbuch (substantiated the applied science "informatics", as a specific field of cybernetics, 1957 [7]), W. Gibson (substantiated "cyberspace" or "digital space" as virtual reality in computer technology, 1982 [11, 12, 13, etc.]), V.O. Chulkov (substantiated the cyberspace of the "person-technics-environment" system as an infographic modeling, 1989-2018 [14, etc.]) and others. The ontology of terms and the interrelation of medical and technical cybernetics are shown in [15]. The summit of the modern development of cybernetics is the concept of cyberspace and the cyber system, in particular, the cyber-physical system (CPS).

The term "cyber-physical systems" was introduced into scientific and practical circulation in 2006 by Helen Gill [16] at the NSF CPS Workshop seminar on integrated and hybrid systems of the US National science foundation. The organizers of this seminar reconsidered the role of integrated systems and came to the conclusion, that to create CPS, capable of working in the real world, a new 
discipline is needed - model engineering or infographic modeling [17].

The cyberphysical system "... integrates computing resources into the physical entities of biological and manmade objects" [18]. These resources in CPS are distributed throughout the physical system and are synergistically linked to its elements "[19]. The computer monitors and manage the physical processes, affecting the calculations, in CPS based on feedback loops [20].

The concept of electronic (digital) economy and the concept of digitalization were proposed by N. Negroponte [21], which intensified the development of digital technologies and led to the development of digital management [22], in particular, in construction [23, etc.]. Its electronic variety differs from the traditional economy by its significant dependence on the Internet of things [24], virtuality, and multilayer digital control [25], organically integrated into it, based on telecommunication networks and computer equipment.

Cyberphysical systems in construction belong [15, 26, etc.] to applied cybernetics, they imply the study of natural phenomena and technical processes from the standpoint of the needs and limitations of a functioning person (designer, builder or building user).

\section{STUDY METHODOLOGY.}

Systemic, comparative and qualitative analysis, infographic modeling and anthropotechnical management were selected as the basis of the study.

\section{STUDY RESULTS}

\subsection{Options for a basic monitoring model}

The principles of the digital economy are topologically interrelated [15] with the principles of evaluation of activity in the cyberphysical system "person-technicsenvironment, PTE [14]", the circular model of which ("triad", fig. 1) demonstrates the interrelation of technical and medical cybernetics.

In the relationship between the components (monads) of the PTE cyberphysical system, we distinguish four options.

Option 1. Any two monads interact with each other (fig. 1, dotted thick double-sided arrows).
Option 2. The interrelation of any two monads is a combination of two oppositely directed effects (fig. 1, three pairs of continuous thin one-sided arrows between the monads of the PTE system). The content of the effects BO1-6 and their results P1-6 in the process of monitoring the dynamics of changes of the human adaptive norm in the cyberphysical systems of "smart buildings" using digitalization is shown in Table 1.

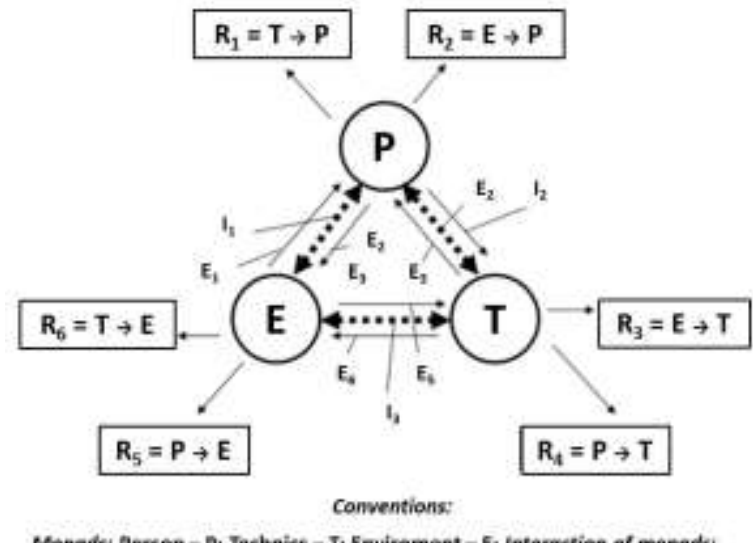

ent $-\mathrm{E}$; interuc $\mathrm{I}_{1}, \mathrm{I}_{2}, \mathrm{I}_{3}$; Effects of monads on each other: $\mathrm{E}_{1}, \mathrm{E}_{2}$; Results of interaction of manads an each other: $R_{1}-R_{6}$ [Chulloav vo., 2016]

Figure 1 Interrelations (interactions and effects) and their results on a circular model of the PTE triad [Chulkov V.O., 2016]

Option 3. The management effect of one monad of the PTE system is aimed at regulating the interaction of two other monads ("loading the interaction of monads", fig. 2); however, the loading monad does not enter into a relations with interacting monads. 
Table 1 The content of the effects E1-6 and their results R1-6 in the process of monitoring the dynamics of changes of the human adaptive norm in the cyberphysical systems of "smart buildings" using digitalization

\begin{tabular}{|c|c|}
\hline Designation & Content \\
\hline PTE & $\begin{array}{l}\text { Infographic model (triad) of monitoring of the dynamics of changes of the human adaptive norm in cyberphysical } \\
\text { systems of "smart buildings" using digitalization }\end{array}$ \\
\hline \multicolumn{2}{|r|}{ Components (monads) of the PTE triad, fig. 1} \\
\hline $\mathbf{P}$ & Person and his mental activity (thinking) in the process of studying the dynamics of changes of his adaptive norm \\
\hline TONES & $\begin{array}{l}\text { Technics - products of a person's mental creative activity, designed as a project [27] and implemented in production } \\
\text { as components of the cyberphysical systems of "smart buildings" }\end{array}$ \\
\hline $\mathbf{E}$ & $\begin{array}{l}\text { Environment is a person's living space in a "smart building", served by cyberphysical systems and allowing a } \\
\text { person to comfortably carry out the processes of vital activity and / or production activity in accordance with his } \\
\text { dynamically changing adaptive norm }\end{array}$ \\
\hline \multicolumn{2}{|r|}{ Interactions of the monads of the PTE triad, fig. 1} \\
\hline $\mathbf{I}_{\mathbf{1}}$ & The interaction of monads $\mathbf{P}$ and $\mathbf{E}, \mathbf{I}_{\mathbf{1}}=\mathbf{P} \leftrightarrow \mathbf{E}$ \\
\hline $\mathbf{I}_{2}$ & The interaction of monads $\mathbf{P}$ and $\mathbf{T}, \mathbf{I}_{2}=\mathbf{P} \leftrightarrow \mathbf{T}$ \\
\hline $\mathbf{I}_{3}$ & The interaction of monads $\mathbf{T}$ and $\mathbf{E}, \mathbf{I}_{3}=\mathbf{T} \leftrightarrow \mathbf{E}$ \\
\hline \multicolumn{2}{|r|}{ The effects of the monads of the PTE triad on each other, fig. 1} \\
\hline $\mathbf{E}_{1}$ & The effect of monad $\mathbf{E}$ on monad $\mathbf{P}, \mathbf{E}_{1}=\mathbf{E} \rightarrow \mathbf{P}$ \\
\hline $\mathbf{E}_{2}$ & The effect of monad $\mathbf{P}$ on monad $\mathbf{E}, \mathbf{E}_{2}=\mathbf{P} \rightarrow \mathbf{E}$ \\
\hline $\mathbf{E}_{3}$ & The effect of monad $\mathbf{T}$ on monad $\mathbf{P}, \mathbf{E}_{3}=\mathbf{T} \rightarrow \mathbf{P}$ \\
\hline $\mathbf{E}_{\mathbf{4}}$ & The effect of monad $\mathbf{P}$ on monad $\mathbf{T}, \mathbf{E}_{\mathbf{4}}=\mathbf{P} \rightarrow \mathbf{T}$ \\
\hline $\mathbf{E}_{5}$ & The effect of monad $\mathbf{E}$ on monad $\mathbf{T}, \mathbf{E}_{\boldsymbol{5}}=\mathbf{E} \rightarrow \mathbf{T}$ \\
\hline $\mathbf{E}_{6}$ & The effect of monad $\mathbf{T}$ on monad $\mathbf{E}, \mathbf{E}_{6}=\mathbf{T} \rightarrow \mathbf{E}$ \\
\hline \multicolumn{2}{|r|}{ The results $R_{1-6}$ of the effect of the monads of the PTE triad on each other, fig. 1} \\
\hline $\mathbf{R}_{1}$ & $\begin{array}{l}\mathbf{R}_{1}=\mathbf{T} \rightarrow \mathbf{P} \text {. This is the result of the effect of the components of the cyber-physical systems of "smart buildings" } \\
\text { on a person in the process of carrying out his mental activity, life activity or industrial activity. Comparing the } \\
\text { results of the instrumental quantitative (digitalized) evaluation of } \mathbf{R}_{\mathbf{1}} \text { with the current adaptive norm of a particular } \\
\text { person, it is determined whether he is in a normal mode of functioning or goes beyond the scope of such a regime } \\
\text { (exposed to the pathogenic effects of technics). }\end{array}$ \\
\hline $\mathbf{R}_{\mathbf{2}}$ & $\begin{array}{l}\mathbf{R}_{2}=\mathbf{E} \rightarrow \mathbf{P} \text {. This is the result of the effect of the living space of a person in a "smart building" on a person in the } \\
\text { process of his implementation of carrying out his mental activity, life activity or industrial activity. Comparing the } \\
\text { results of the instrumental quantitative (digitalized) evaluation } \mathbf{R}_{2} \text { with the current adaptive norm of a particular } \\
\text { person, it is determined whether he is in a normal mode of functioning or goes beyond the scope of such a regime } \\
\text { (exposed to pathogenic environmental effects). }\end{array}$ \\
\hline $\mathbf{R}_{3}$ & $\begin{array}{l}\mathbf{R}_{3}=\mathbf{E} \rightarrow \mathbf{T} \text {. This is the result of the analysis of how well-developed environment of the "smart building" allows } \\
\text { to provide a person with comfortable mental activity, life activity or industrial activity when the components of } \\
\text { the cyberphysical systems of the "smart building" function. The rationing of such an interconnection of E and T } \\
\text { monads implies a rational combination of their antagonistic interests by the criterion of human comfort within the } \\
\text { framework of its dynamically changing adaptive norm. }\end{array}$ \\
\hline $\mathbf{R}_{4}$ & $\begin{array}{l}\mathbf{R}_{4}=\mathbf{P} \rightarrow \mathbf{T} \text {. This is the result of evaluation of the degree of possibility and dynamics of human adaptation to the } \\
\text { requirements of the technology of functioning of the components of the cyberphysical systems of the "smart } \\
\text { building" based on digitalization. Such an opportunity and the required dynamics of adaptation should be within } \\
\text { the limits of the adaptive norm of a particular person. Achieving the necessary level of functioning of } \\
\text { cyberphysical systems in a "smart building" is directly related to the problems of training and improving the } \\
\text { competence of the housing user. }\end{array}$ \\
\hline $\mathbf{R}_{\mathbf{5}}$ & $\begin{array}{l}\mathbf{P}_{\mathbf{R}}=\mathbf{P} \rightarrow \mathbf{E} \text {. This is the result of evaluation of the degree of possibility and dynamics of a person's adaptation to } \\
\text { the parameters and specifics of the living environment of a "smart building". In the process of such adaptation, a } \\
\text { specific person proceeds from the capabilities of his individual adaptive norm and can take certain steps to } \\
\text { "improve" monad } \mathbf{E} \text {, which are seemed correct. Such "improvement" may conflict with the requirements and } \\
\text { norms of functioning of the cyber-physical systems of a "smart building" ". }\end{array}$ \\
\hline $\mathbf{R}_{6}$ & $\begin{array}{l}\mathbf{R}_{\mathbf{6}}=\mathbf{T} \rightarrow \mathbf{E} \text {. This is the result of the analysis of how the functioning of the components of the cyberphysical } \\
\text { systems of "smart building" influence on the functioning and transformation of the human environment. As a } \\
\text { result, it is necessary to quantitatively evaluate (using the possibilities of digitalization and computerization of } \\
\text { such an evaluation) how this influence is combined with the capabilities of the adaptive norm of a particular } \\
\text { person. }\end{array}$ \\
\hline
\end{tabular}




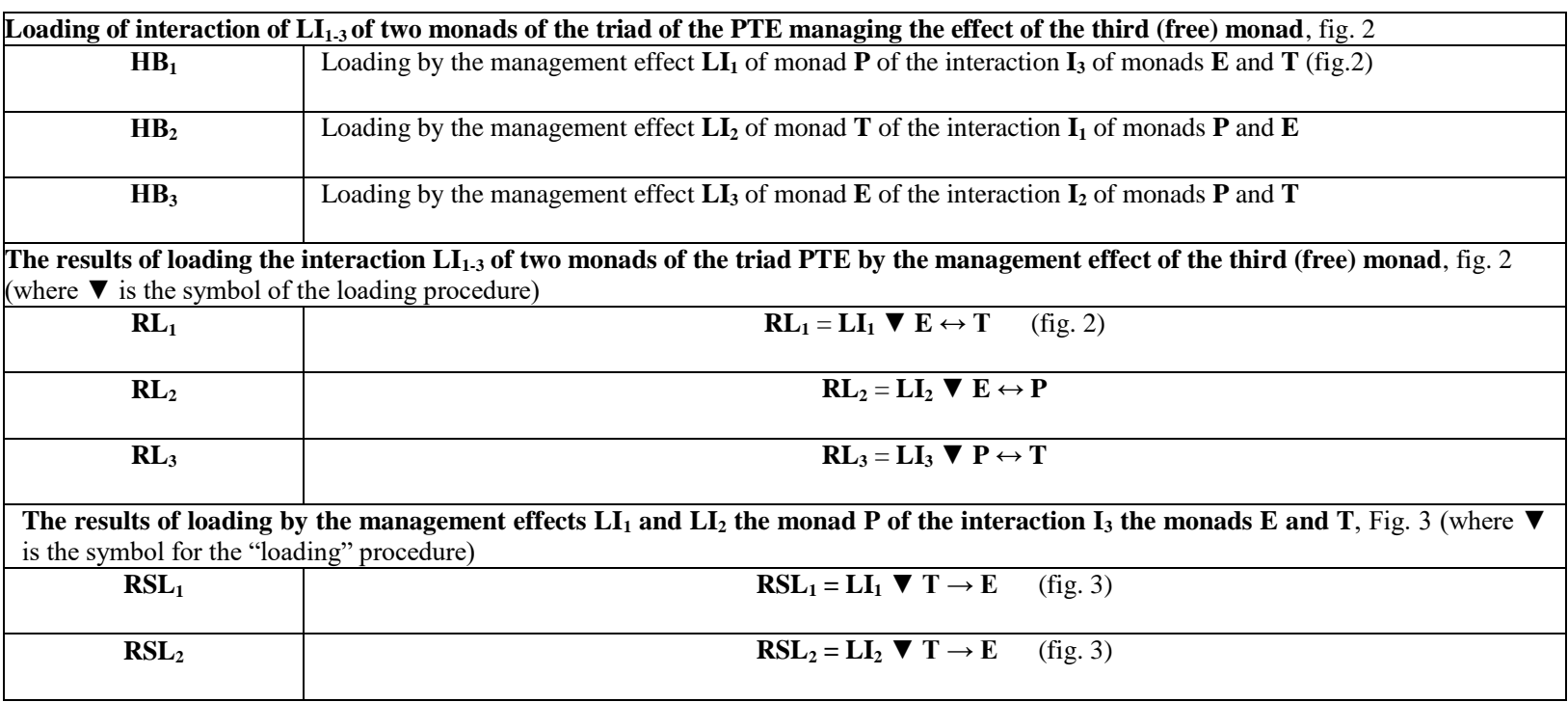

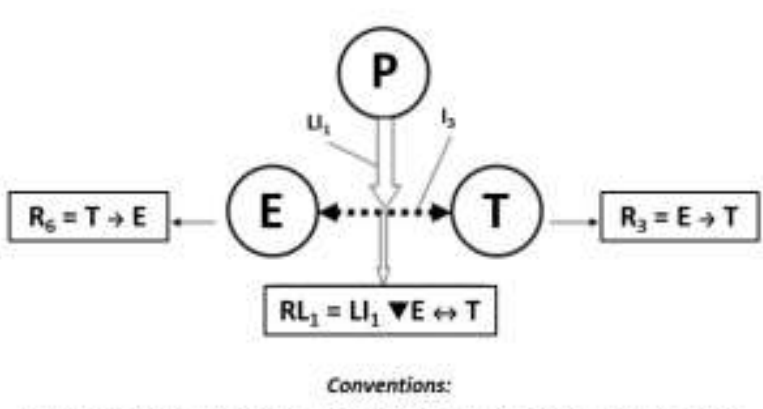

Monads: Person - $P$; Technics $-T$; Enviroment $-E$; interaction of manods $E$ And $T: I_{3}$, The management effect (looding) of manad $P$ on the interaction $\mathrm{I}_{3}$ of monads $\mathrm{E}$ and $\mathrm{T}: \mathrm{U}_{4} ;$ Resuits of loading by the management effects of monod $\mathrm{P}$ of interaction $\mathrm{I}_{4}$ of monods $\mathrm{E}$ and $\mathrm{T}: \mathrm{RL}_{1}$ [Chulkov V.O., 2016]

Figure 2 Interrelations ("loading the interaction of monads") and their results on a circular model of the PTE triad [Chulkov V.O., 2016]

Option 4. The management effect of one of the three monads of the PTE system are directed separately to each of the remaining two monads, interacting with each other, ("separate loading of two interacting monads", fig. 3).

Models of the interrelation options between the components of the PTE cyberphysical system (fig. 1 - 3) work at all five levels of the multilayer hierarchical model of digitalization of management in cyberphysical systems (fig. 4, Chulkov V.O., 2018 [15]).

\subsection{Digitalization of monitoring the human adaptive norm in the cyberphysical systems of "smart buildings"}

The procedures and results of monitoring of the dynamics of changes of the human adaptive norm in the cyberphysical systems of "smart buildings" are conditionally divided into several successively carried out stages [27, etc.].

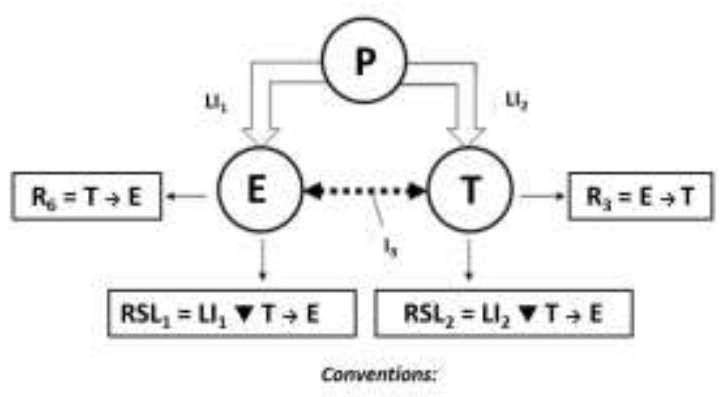

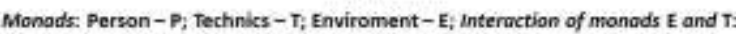
13; The separate manogement effects (laadings) of manad P an the interaction mannds $\mathrm{E}$ and $\mathrm{T}: \mathrm{U1}, \mathrm{U2}$; Results of loading interactian manods $\mathrm{E}$ and $\mathrm{T}$ by the separate management effects of monad: RSL1, RSL2 [Chulkov V.O., 2016]

Figure 3 Interrelations ("separate loading of two interacting monads") and their results on a circular model of the PTE triad [Chulkov V.O., 2016] 


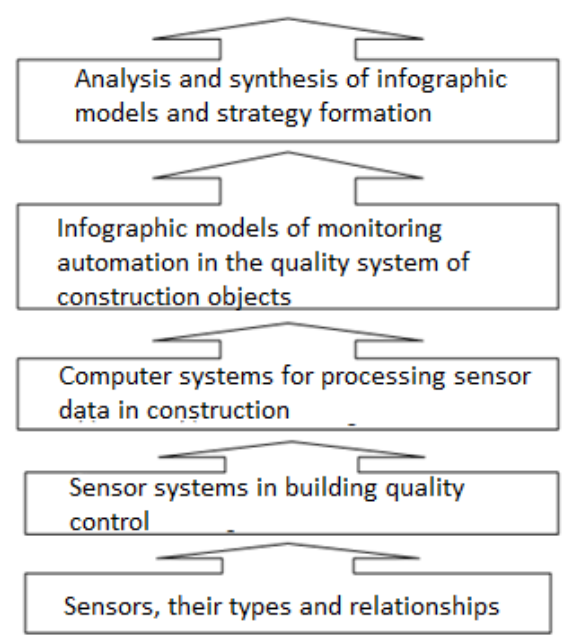

Figure 4. Multilayer hierarchical infographic model of digitalization of management in cyberphysical systems (Chulkov V.O., 2018).

\section{Stage 1:}

- development of an organizational and technological monitoring plan;

- the formation of the composition and structure of the studied parameters, characterizing the human adaptive norm;

- selection of intermediate diagnostic modes of parameter values;

- technical and software adaptation of the hardware of the diagnostic equipment to the functioning modes of the cyberphysical systems of a particular housing;

- experiment planning; preparation of study operators and investigated people to conduct study in specific conditions.

Stage 2:

- obtaining digitalized values of the diagnostic parameters of the adaptive norm of a particular examined person under the conditions of functioning of the cyberphysical systems of the "smart building"

- taking into account the possible influence of threshold changes of the standard properties of the environment on the hardware of the diagnostic equipment during the experiment due to additional "shooting" of the test object in each series of gas-discharge visualization based on the Kirlian effect [28].

Stage 3:

- detecting deviations of the digitalized values of the diagnostic parameters of the adaptive norm of a particular examined person from the "reference" value (obtained in the "clean room" [27]);

- formation of recommendations on compensation of pathogenic effects of the environment of the "smart home" on this person.

Modern technical implementation of the gas-discharge visualization method allows to safely shoot with bursts of pulses from $1 / 24$ second to several minutes and voltage in the discharge chamber from 16 to $25 \mathrm{kV}$. The shooting time for all 10 terminal phalanges of the fingers varies from 3-5 to 15 minutes depending on the shooting mode [29].

The procedure for conducting a session of diagnostic measurements of parameter values with the indispensable digitalization of the results for transmitting and processing them in real time in the monitoring technology was adjusted depending on the specific organizational conditions and the possibilities of the technical execution of the diagnostic procedures.

On modern portable computers with Windows 9x-XP operating systems, the Hibernate "sleep" mode is implemented - hot "damping" of the computer without uploading running drivers and programs with the ability to completely disconnect from external and internal power sources. A computer in this mode can be ready to participate in the examination again together with all initially running programs and devices in less than one minute.

\section{DISCUSSING THE RESULTS}

With a relatively small operator skill, tenfold shooting of the test object takes 10 seconds, and ten fingers are shot in the first mode of the gas-discharge diagnostic method with saving of the results on the hard drive for $1.5-3.5$ minutes. The total preparation time for shooting, shooting a test object and shooting in the first mode of a gasdischarge method for diagnosing ten fingers of a diagnosed person with subsequent folding of a hardwaresoftware complex takes averages no more than five minutes.

In the vast majority of cases of diagnostics, the psychophysical characteristics of the adaptive norm of the human body change most rapidly during functioning. Diagnostics by the gas-discharge method is an additional load with electromagnetic fields and radiation on the human body. Although there are still no officially approved current standards for the allowable number of 
digitalization hierarchy of management in cyberphysical systems (fig. 4) is an actual scientific problem, that needs to be solved. The Association "Infographic basis of functional systems" of the Russian section of the International Academy of Sciences is actively exploring this problem.

\section{REFERENCES}

[1] Khramov YU.A. Istoriya fiziki.- Kiyev: Feniks, 2006.- 1176s.

[2] Berg A.I. Osnovnyye voprosy kibernetiki // Istoriya informatiki $\mathrm{v}$ Rossii: uchenyye i ikh shkoly / Redaktory-sostaviteli: V.N. Zakharov, R.I. Podlovchenko, YA.I. Fet.- M.: Nauka.- 2003.

[3] Bogdanov A.A. Tektologiya. Vseobshchaya organizatsionnaya nauka.- $\mathrm{V}$ 2-kh kn.- M.: «Ekonomika», 1989.- Kn.1 - 304s., Kn. 2 - 351s.

[4] Bertalanffy L. von. General System Theory // General Systems.- Vol.I.- 1956.- P.1-10.

[5] Sudakov K.V. Funktsional'nyye sistemy.- M.: Izdatel'stvo RAMN, 2011.- 320s.

[6] Fon Neyman, Dzh. Teoriya samovosproizvodyashchikhsya avtomatov / Per. s angl.M.: Izd-vo "Mir", 1971.-384s.

[7] Fon Neyman, Dzh. Vychislitel'naya mashina i mozg.- Kiberneticheskiy sbornik, №1.- M.: Inostrannaya liteoratura, 1960.- S.11-60 (rukopis' 1955$56 \mathrm{gg})$.

[8] Wiener N. Cybernetics or Control and Communication in the Animal and the Machine.- New York: The Technology Press and John Wiley \& Sons, Inc.- Paris: Hermann et Cie, 1948.

[9] Wiener N. Cybernetics or Control and Communication in the Animal and the Machine.- 2nd ed.- New York - London: The M.I.T. Press and John Wiley \& Sons, Inc., 1961.

[10] Steinbuch K. Informatik: Automatische Informationsverarbeitung // SEG-Nachrichten (Technische Mitteilungen der Standard Elektrik Gruppe) - Firmenzeitschrift.- 1957. 
[21] Negroponte N. Being Digital / N. Negroponte.-

[11] William Gibson, Neuromancer. New York: Ace Books, 1984. (U.Gibson Kiberprostranstvo, trilogiya, 1984-1988).

[12] Alexander Klimburg, Philipp Mirtl. Cyberspace and Governance - A Primer. The Austrian Institute for International Affairs, Working Paper 65 / September 2012.

[13] Kiberprostranstvo.- [Elektronnyy resurs].- Rezhim dostupa: http://ru.knowledgr.com/00004500/ Data obrashcheniya 10.2.2020

[14] Chulkov V.O. Antropotekhnika infograficheskogo modelirovaniya $\mathrm{v}$ upravlenii: Modul'nyy kurs lektsiy.T.4.- Moduli 152-154.- M.: Russkaya shkola, 2019.S.284-317.

[15] Chulkov V.O., (2019) Modeling of digitalization of management in cyber-physical systems of reorganization of residential territories.- Advances in Economics, Business and Management Research, volume 105, pp.640-644.

[16] Chernyak L. Kiberfizicheskiye sistemy na starte // Otkrytyye sistemy. SUBD.- 2014.- №2.- S.10-15. URL: https://www.osp.ru/os/2014/02/ 13040038 (data obrashcheniya: 6.05.2019).

[17] Lovin B.A., Kazaryan R.R., Chulkov V.O. Infografiya antropotekh-nicheskogo menedzhmenta: Nauchnoye izdaniye: v 3t. / Pod red. V.O.Chulkova.M.: FGBU DPO «Uchebno-metodicheskiy tsentr po obrazovaniyu na zheleznodo-rozhnom transporte», 2016.- 932s., il.

[18] Kiberfizicheskaya https://ru.wikipedia.org/wiki/ Kiberfizi-cheskaya sistema (data obrashcheniya: 6.05.2019).

[19] R.G.Sanfelice, (2016) Analysis and Design of Cyber-Physical Systems. A Hybrid Control Systems Approach // Cyber-Physical Systems: From Theory to Practice / D. Rawat, J. Rodrigues, I. Stojmenovic.- CRC Press, 2016.- ISBN 978-1-4822-6333-6.

[20] Lee E.A. (2015) The Past, Present and Future of Cyber-Physical Systems: A Focus on Model Cheng AMK, ed. // Sensors (Basel). Vol. 15(3), March, 2015, 4837-4869.
NY : Knopf, 1995 [Elektronnyy resurs]. URL: http://inance.ru/2017/09/cifrovaya-ekonomika/ (data obrashcheniya: 10.08.2019).

[22] Natsional'naya tsifrovizatsiya [Elektronnyy resurs].- https:// rostec.ru/ analytics/natsionalnayatsifrovizatsiya/ (data obrashcheniya: 10.08.2019).

[23] Khalin V.G., Chernova G.V. Tsifrovizatsiya i yeyo vliyaniye na ros-siyskuyu ekonomiku i obshchestvo: preimushchestva, vyzovy, ugrozy i riski // Upravlencheskoye konsul'tirovaniye.- №10.- 2018 .S.46-63.

[24] Chernyak L. Internet veshchey: novyye vyzovy i novyye tekhnologii // Otkrytyye sistemy. SUBD.2013.- №4.- S.14-18. URL: http://www.osp.ru/ os/2013/04/13035551 (data obrashcheniya: 10.05.2019).

[25] Mnogosloynaya model' vychislitel'noy seti.http://iteranet.ru/it-novosti/2014/03/18/mnogoslojnayamodel-vychislitelnoj-seti/ (data obrashcheniya: 1.07.2019)

[26] Volkov A.A. Kibernetika stroitel'nykh sistem. Kiberfizicheskiye stroitel'nyye sistemy // Promyshlennoye i grazhdanskoye stroitel'stvo.- №9.2017.- S.4-7.

[27] Bezopasnost' zhiznedeyatel'nosti. Organizatsionno-antropotekhni-cheskaya nadozhnost' funktsional'nykh sistem mobil'noy sredy stroitel'nogo proizvodstva. Seriya «Infograficheskiye osnovy funktsional'nykh sistem»/Pod red. V.O.Chulkova.M.:Izd-vo ASV, 2003.- 176s., il.

[28] Chulkov V.O., Masturov I.YA. Kompleksnaya antropotekhnicheskaya inzhenernaya metodika priborno-analiticheskoy diagnostiki i kompensatsii urovnya komfortnosti cheloveka v srede obitaniya.- M.: TSNIIOMTP, Laboratoriya ITEBZH, 2002.- 52s.

[29] Smirnov P.N. Avtomatizirovannoye proyektirovaniye tekhnologii diagnostiki kachestva mobil'noy sredy obitaniya $\mathrm{v}$ stroitel'stve.- M.: INO, 2002.- №2.- Infografiya v sistemotekhnike.- S.60-74.

[30] Tsvetkov V.YA. Kiberfizicheskiye sistemy // Mezhdunarodnyy zhurnal prikladnykh i 
fundamental'nykh issledovaniy.- 2017.- № 6-1.- S.64-

65 ;

URL:

https://applied-

research.ru/ru/article/view?id=11623

(data

obrashcheniya 29.09. 2019).

[31] Yastreb N.A. Industriya 4.0: kiberfizicheskiye sistemy, razumnoye okruzheniye, Internet veshchey.https://techno.vogu35.ru/docs/2015/Industria

4_0_Yastreb.pdf (data obrashcheniya 29.09. 2019).

[32] Shaitura S.V., Stepanova M.G., Shaitura A.S., Ordov K.V., Galkin N.A. Application of informationanalytical systems in management // Journal of Theoretical and Applied Information Technology.2016.- V. 90.- № 2.- C. 10-22. 